\title{
DEVELOPMENT OF TRANSPORT INFRASTRUCTURE IN RIVNE OBLAST: SPATIAL DIFFERENCES
}

\author{
Iryna OSIPCHUK \\ International University of Economics and Humanities named after academician Stepan Demianchuk, Rivne, Ukraine \\ Osipchukira@ukr.net
}

\begin{abstract}
The article deals with the human-geographical approaches to the study of regional transport infrastructure, in particular by using the Engel's coefficient, index of territorial connectivity and, finally, index of regional territorial connectivity, offered by the author. The analysis focuses on the territorial differences (by the administrative raions of Rivne oblast) in the development of transport infrastructure for all modes of transport: roads by type (highways, national, regional, territorial, provincial, and rural roads); railway tracks by type (single-track, double-track, narrow-gauge) and stations (passenger, cargo, and linear); air transport. Further studies of the regional transport infrastructure may imply the public availability of bus and railway transport, as well as a qualitative assessment of roads, railways and rolling stock.

Key words: transport infrastructure, Engel's coefficient, connectivity index, index of regional territorial connectivity, transport of Rivne oblast
\end{abstract}

UDC: 911.3

\section{ТЕРИТОРІАЛЬНІ ВІДМІННОСТІ РОЗВИТКУ ТРАНСПОРТНОЇ ІНФРАСТРУКТУРИ РІВНЕНСЬКОЇ ОБЛАСТІ}

\author{
Ірина ОСІПЧУК \\ Міжнародний економіко-гуманітарний університет імені академіка Степана Дем'янчука, м. Рівне, Україна \\ Osipchukira@ukr.net
}

\begin{abstract}
Анотація: Розглянуто суспільно-географічні підходи щодо дослідження транспортної інфраструктури регіону, зокрема за допомогою обрахунку коефіцієнту Енгеля, індексу комунікативності території та запропонованого у статті індексу територіальної комунікативності регіону. Здійснено аналіз територіальних відмінностей у розрізі адміністративних районів Рівненської області у розвитку транспортної інфраструктури за всіма представленими видами транспорту - автомобільних шляхів за усіма типами (магістралі, національні, регіональні, територіальні, обласні та сільські автомобільні дороги); залізничних шляхів за типами (одноколійні, двоколійні, вузькоколійні) та станцій (пасажирські, вантажні та лінійні); авіатранспорту. Перспективою подальшого дослідження транспортної інфраструктури області може бути врахування забезпеченості населення автобусною маршрутною мережею та залізничного сполучення території, а також якісна оцінка автомобільних шляхів, залізниць та рухомого складу.

Ключові слова: транспортна інфраструктура, коефіцієнт Енгеля, індекс комунікативності, індекс територіальної комунікативності регіону, транспорт Рівненської області
\end{abstract}

удк: 911.3

Вступ. Постановка проблеми. Транспортна інфраструктура регіону -це його кровоносна система, що створює умови для реалізації більшості товарів та послуг в умовах постійно зростаючого поглиблення територіального та суспільного поділу праці. Її структура та рівень розвитку як безпосередньо, так і опосередковано, впливає на всі сфери життєдіяльності населення певної території. Особливої уваги дослідження транспортної інфраструктури регіону заслуговує під час підготовки до адміністративно-територіальної реформи, що передбачає укрупнення адміністративних одиниць, оскільки це означатиме зростання показників часової та територіальної доступності адміністративних та інших послуг для сільського населення. Тому для Рівненської області, де переважає сільське населення, питання доступності товарів та послуг вищого рангу для населення сіл є особливо актуальним.

Як відомо, за рядом показників Рівненську область відносять до депресивних регіонів України.

(C) I. Осіпчук
Проте, завдяки своєму суспільно-географічному положенню територія області не може залишитися осторонь під час формування торговельних потоків із країнами СС.

Дослідження транспортної інфраструктури регіону набуває всезростаючого значення під час розвитку міжрегіональної та міждержавної торгівлі та сфери послуг. Проте, навіть у межах одного регіону часто існують суттєві диспропорції у рівні розвитку транспортної інфраструктури та окремих їі компонентів.

Аналіз останніх досліджень і публікацій. Дослідження територіальних аспектів функціонування транспорту були започатковані у працях німецьких вчених I. Канта та А. Гетнера як засобу подолання простору, О. Блюм, Э. Шейен, Р. Гауфе - обгрунтували самостійність географії транспорту. За радянських часів питанням територіальної організації транспорту були присвячені праці І. В. Нікольского, Н. Н. Казанського, В. М. Бугроменка та ін. Серед сучасних українських дослідників у даній галузі варто відзначити 
B. I. Дорошенка, М. I. Дудника, I. Г. Смирнова, О. І. Шаблія та інших.

Формулювання цілей статті. Постановка завдання. Метою статті $є$ аналіз територіальних відмінностей у розвитку транспортної інфраструктури та окремих іiі складових за адміністративними районами Рівненської області, виявлення територіальних диспропорцій у показниках забезпеченості населення території елементами транспортної інфраструктури.

Виклад основного матеріалу. Суспільногеографічне дослідження транспорту включає не всю транспортну галузь, а лише її частину інфраструктуру у вузькому сенсі як найбільш прив'язану до території і таку, що має міжгалузевий характер. До транспортної інфраструктури відносять наземні, водні та повітряні шляхи, трубопроводи, морські та річкові порти, залізничні станції, аеропорти, транспортні термінали, метрополітени, транспортні розв'язки та різні споруди транспортного комплексу.

Рівень розвитку транспортної інфраструктури накладає сильний відбиток на економічному та соціальному потенціалі території.

У Рівненській області, відповідно до i. географічного положення, природних умов та рівня соціально-економічного розвитку, розвиваються наземні транспортні шляхи - автомобільні та залізничні. $€$ також міжнародний аеропорт, який на даному етапі не приймає регулярних рейсів.

Мережа автомобільних иляхів для Рівненщини має ключове значення, адже вона має протяжність понад 5 тис км, що складає 90 \% наземних шляхів області із середньою густотою - 251 км на тис км кв. У їх структурі присутні усі види автомобільних шляхів, що виділяють в Україні - міжнародні, національні, регіональні, територіальні, обласні та сільські.

Міжнародні автомобільні дороги складають 7 \% від загальної протяжності автомобільних шляхів у області і представлені трьома шляхами:

- M-06 (Київ - Чоп) - близько 175 км у межах області;

- М-07 (Київ - Ковель - Ягодин (на Люблін)) близько 110 км;

- М-19 (Доманове (на Брест) - Ковель - Чернівці - Тереблече (на Бухарест)) - близько 70 км.

Національні автомобільні дороги на Рівненщині представлені лише одним шляхом Н-22 (Устилуг - Луцьк - Рівне) протяжністю близько 36 км, що складає лише 0,7 \% усіх шляхів.

На регіональні автомобільні дороги припадає 6,2 \% автомобільних шляхів області і вони мають загальну протяжність близько 310 км:

- Р-05 (Городище - Рівне - Старокостянтинів (через Сарни)) - 210 км;

- Р-66 (Острог - Кременець - Почаїв - Радивилів) -30 км;

- Р-77 (Рівне - Тучин - Гоща) - 70 км.

Територіальні автомобільні дороги загального користування у Рівненській області мають код Т-18 і їх налічується 32 - від Т-18-01 до Т-18-33 (Т-18-07 було переведено у статус регіональної дороги Р-77). Також по території Рівненщини проходить три шляхи Волинської області із шифром Т-03. Загальна протяжність територіальних автошляхів на території області складає близько 1190 км, що становить майже чверть усіх шляхів області. У середньому густота цих шляхів по території області становить 59 км на тис км² - від 169 км / тис км² у Демидівському, 105 у Здолбунівському до 17 - у Зарічненському та 25 у Гощанському.

Обласних автомобільних доріг загального користування у області налічується 211. Їх шифр складається з літери «О» та 6 цифр: О-18-хх-уу, де хx номер району від 01 до 16, а уу - номер по порядку. Їх загальна протяжність складає 2290 км, що становить понад 45 \% загальної протяжності автошляхів області. Найбільша їх протяжність у Володимирецькому (220 км), Дубенському (196) та Гощанському (190 км) районах, а густота - у Гощанському, Дубенському та Здолбунівському районах.

Остання група - це сільські автомобільні дороги загального користування. Їх у Рівненській області налічується 208 загальною протяжністю понад 850 км, що складає 17 \% автошляхів області. Шифр таких автошляхів складається аналогічно попередньому виду, лише на початку замість літери «О»- літера «С». Найбільша їх протяжність у Дубенському, Рівненському і Сарненському районах, а густота - у Рівненському, Дубенському і Радивилівському.

Залізничні шляхи Рівненщини відносяться до Львівської залізниці, за виключенням одного відгалуження у Острозькому районі, що належить до Південно-Західної. Їх загальна протяжність складає 575 км - 10 \% наземних шляхів області - і половина припадає на одноколійні, третина - на двоколійні і 20 \% - на вузькоколійку. Вузькоколійна залізниця «Антонівка - Зарічне» (також відома як «Кукушка» чи «Поліський трамвай») - проходить територією Володимирецького i Зарічненського районів i $\epsilon$ найдовшою (106 км) діючою вузькоколійною залізницею в Європі. Вона була побудована у 1895 р i в іiі обслуговуванні досі використовується чимала кількість раритетної техніки.

Як видно із табл. 2, найбільша протяжність залізниць у області сконцентрована у Володимирецькому, Сарненському, Рівненському і Зарічненському районах, а найвища їх густота - у Дубенському і Рівненському районах. У Гощанському, Корецькому, Млинівському і Демидівському районах вони взагалі відсутні.

Всього у Рівненській області налічується 66 залізничних станцій, 63 із яких є лінійними i лише 2 - у Сарнах і Здолбунові - є пасажирськими, а одна - Рівному - вантажною. Найбільше лінійних станцій сконцентровано у Рівненському районі - 13 та у Дубенському - 9.

Аеропорт Рівне (Обласне комунальне підприємство «Міжнародний аеропорт Рівне») має одну злітно-посадкову смугу довжиною 2626 м і завширшки 42 м і розташований на відстані 8 км від центру Рівного. На території аеропорту знаходяться: каси по продажу авіаквитків, представництва 


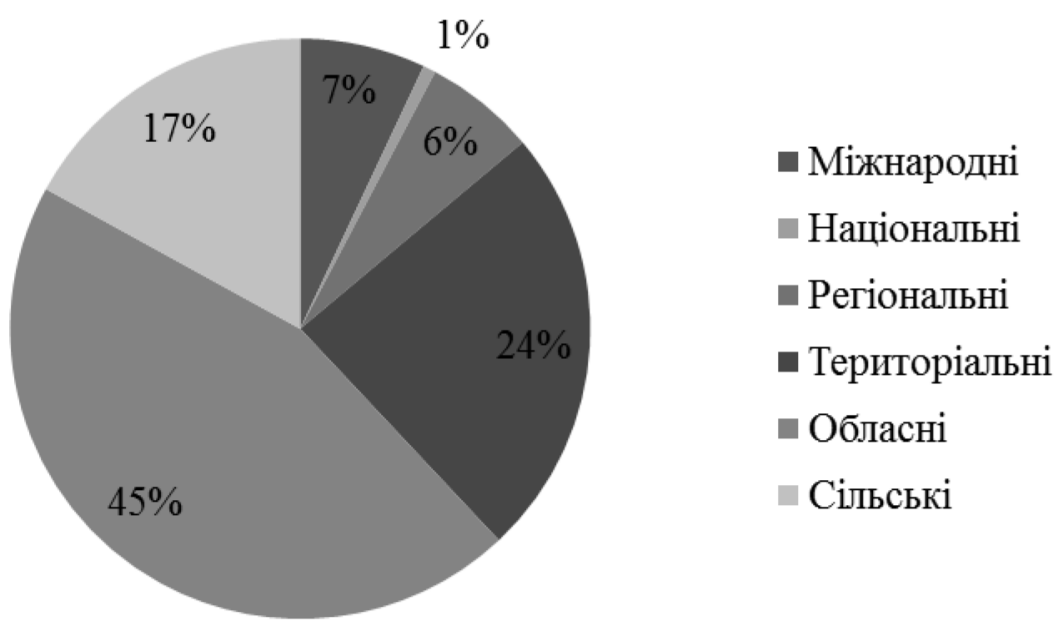

Рис. 1. Структура автомобільних шляхів Рівненської області за протяжністю

Таблиия 1

Протяжність автомобільних доріг Рівненської області за типами у розрізі адміністративних районів, км

\begin{tabular}{|c|c|c|c|c|c|c|c|}
\hline & 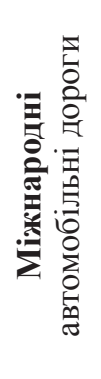 & 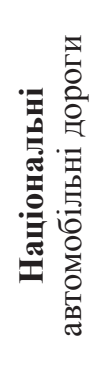 & 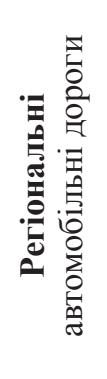 & 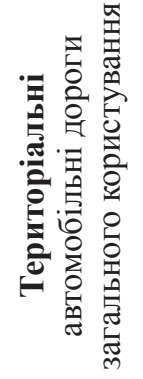 & 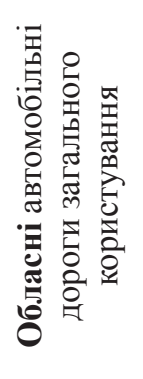 & 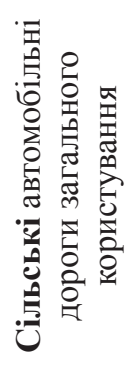 & 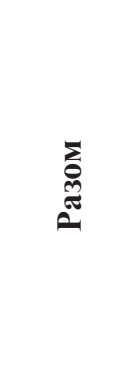 \\
\hline Березнівський & - & - & 23 & 119 & 158,0 & 14,6 & 314,6 \\
\hline Володимирецький & 30 & - & - & 81 & 219,8 & 35,4 & 366,2 \\
\hline Гощанський & 26 & - & 25 & 17 & 189,1 & 39,0 & 296,1 \\
\hline Демидівський & - & - & - & 61 & 74,8 & 11,3 & 147,1 \\
\hline Дубенський & 88 & - & - & 73 & 195,8 & 86,3 & 443,1 \\
\hline Дубровицький & - & - & 50 & 110 & 120,8 & 62,4 & 343,2 \\
\hline Зарічненський & - & - & - & 25 & 150,0 & 46,8 & 221,8 \\
\hline Здолбунівський & 3 & - & 19 & 69 & 158,4 & 27,2 & 276,6 \\
\hline Корецький & 27 & - & - & 52 & 117,8 & 35,3 & 232,1 \\
\hline Костопільський & - & - & 24 & 70 & 168,1 & 59,2 & 321,5 \\
\hline Млинівський & 29 & - & - & 79 & 131,7 & 62,6 & 302,3 \\
\hline Острозький & - & - & 57 & 25 & 110,1 & 48,2 & 240,3 \\
\hline Радивилівський & 32 & - & 21 & 49 & 174,4 & 55,5 & 331,9 \\
\hline Рівненський & 39 & 36 & 61 & 56 & 119,5 & 118,5 & 430,0 \\
\hline Рокитнівський & 32 & - & - & 189 & 61,3 & 48,5 & 330,8 \\
\hline Сарненський & 45 & - & 32 & 112 & 135,1 & 100,9 & 425,0 \\
\hline Рівненська область & 351 & 36 & 312 & 1187,7 & 2284,7 & 851,7 & 5023,1 \\
\hline $\begin{array}{l}\text { Частка у структурі } \\
\text { автошляхів області }\end{array}$ & $7,0 \%$ & $0,7 \%$ & $6,2 \%$ & $23,6 \%$ & $45,5 \%$ & $17,0 \%$ & $100,0 \%$ \\
\hline
\end{tabular}

Складено за матеріалами [2] 
Таблиия 2

Структура залізничних шляхів та станцій Рівненської області за адміністративними районами

\begin{tabular}{|c|c|c|c|c|c|c|c|c|}
\hline & \multicolumn{4}{|c|}{ Протяжність залізничних шляхів, км } & \multirow[b]{2}{*}{ 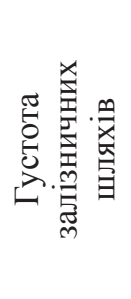 } & \multicolumn{3}{|c|}{ Залізничні станції, од. } \\
\hline & 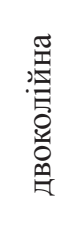 & 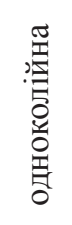 & 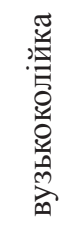 & 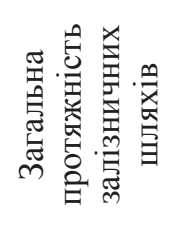 & & 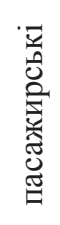 & 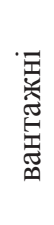 & 寻 \\
\hline Березнівський & & 22 & & 22 & 12,2 & & & 1 \\
\hline Володимирецький & & 35 & 57 & 92 & 47,1 & & & 5 \\
\hline Гощанський & & & & $\mathbf{0}$ & 0,0 & & & \\
\hline Демидівський & & & & $\mathbf{0}$ & 0,0 & & & \\
\hline Дубенський & 55 & 20 & & 75 & 60,3 & & & 9 \\
\hline Дубровицький & & 37 & & 37 & 20,3 & & & 5 \\
\hline Зарічненський & & & 51 & 51 & 35,4 & & & 2 \\
\hline Здолбунівський & 28 & 5 & & 33 & 48,6 & 1 & & 4 \\
\hline Корецький & & & & $\mathbf{0}$ & 0,0 & & & \\
\hline Костопільський & & 24 & & 24 & 15,4 & & & 4 \\
\hline Млинівський & & & & $\mathbf{0}$ & 0,0 & & & \\
\hline Острозький & 25 & & & 25 & 35,5 & & & 3 \\
\hline Радивилівський & 30 & & & 30 & 40,3 & & & 5 \\
\hline Рівненський & 40 & 27 & & 67 & 54,3 & & 1 & 13 \\
\hline Рокитнівський & & 35 & & 35 & 14,9 & & & 5 \\
\hline Сарненський & & 84 & & 84 & 42,6 & 1 & & 7 \\
\hline Разом по області & 178 & 289 & 108 & 575 & 28,5 & 2 & 1 & 63 \\
\hline
\end{tabular}

Складено за матеріалами [3]

авіакомпаній, пункт митного контролю, прикордонний пост, служба перевезень, зал офіційних делегацій, авіа довідка. Послугами аеропорту користується ТОВ «Авіаоптім», базується декілька українських і закордонних авіакомпанії. Основна увага тут приділяється створенню сприятливих умов для діяльності ділових осіб, невеликих туристичних груп, бізнес-польотів, поштових перевезень. Станом на сьогодні проводиться робота по ремонту та реконструкції частини аеровокзального комплексу.

Аеропорт має можливості у подальшому розвитку інфраструктури для надання додаткових послуг представництвам авіакомпаній, туристичним агентствам, населенню та гостям міста.

Територія Рівненської області є неоднорідною у плані господарського освоєння, сформованої поселенської мережі та природних умов. Відповідно, рівень забезпеченості населення транспортною інфраструктурою у різних частинах області не $є$ однаковою.

Для суспільно-географічної оцінки такої забезпеченості використовують ряд показників. Одним із найвідоміших $є$ коефіцієнт Енгеля, що демонструє рівень транспортної доступності із врахуванням площі території та кількості населення як середнє геометричне густоти шляхів сполучення по території і по населенню (1):

$$
K_{E}=L / \sqrt{S N},
$$

де L - загальна протяжність шляхів сполучення, S - площа досліджуваної території, $\mathrm{N}$ - кількість населення у межах досліджуваної території.

У середньому по території України він складає 37, а Рівненської області, як видно на рис.2, - 51 (від 35 на півночі області у Рокитнівському районі, до 81 на півдні області у Радивилівському).

Проте, даний коефіцієнт не враховує якісні характеристики автошляхів, а також розміщення станцій на залізничних шляхах. Ці компоненти враховані у індексі комунікативності території (2):

$l_{k}=0,05 x+0,1 x_{1}+0,2 x_{2}+0,3 x_{3}+0,1 y+0,2 y_{1}+$ $+0,3 y_{2}+0,5 y_{3}+\ldots+0,6 z_{1}+1,0 z_{2}+0,5 k_{1}+$ $+1,0 k_{2}^{2}+0,1 t+0,2 t_{1}+0,3 t_{2}$

де $l_{k}$ - індекс комунікативності, $x$ - вузькоколійні залізниці, $x_{1}$ - одноколійні залізниці; $x_{2}-$ двоколійні залізниці; $x_{3}$ - триколійні залізниці; $y$ - місцеві автошляхи; $y_{l}$ - територіальні автошляхи; $y_{2}$ - регіональні автошляхи; $y_{3}-$ магістральні автошляхи; $z_{1}$ - річкові порти; $z_{2}$ - морські порти; $k_{1}$ - внутрішні аеропорти; $k_{2}^{2}$ - міжнародні аеропорти; $t$ - лінійні залізничні станції; $t_{1}$ - вантажні, передаточні та вузлові залізничні станції; $t_{2}$ - пасажирські, сортувальні, дільничні залізничні станції [1, с. 54-55].

Оскільки регулярних внутрішньодержавних чи міжнародних рейсів аеропорт Рівне не приймає, він не був включений до обрахунку даного індексу. 


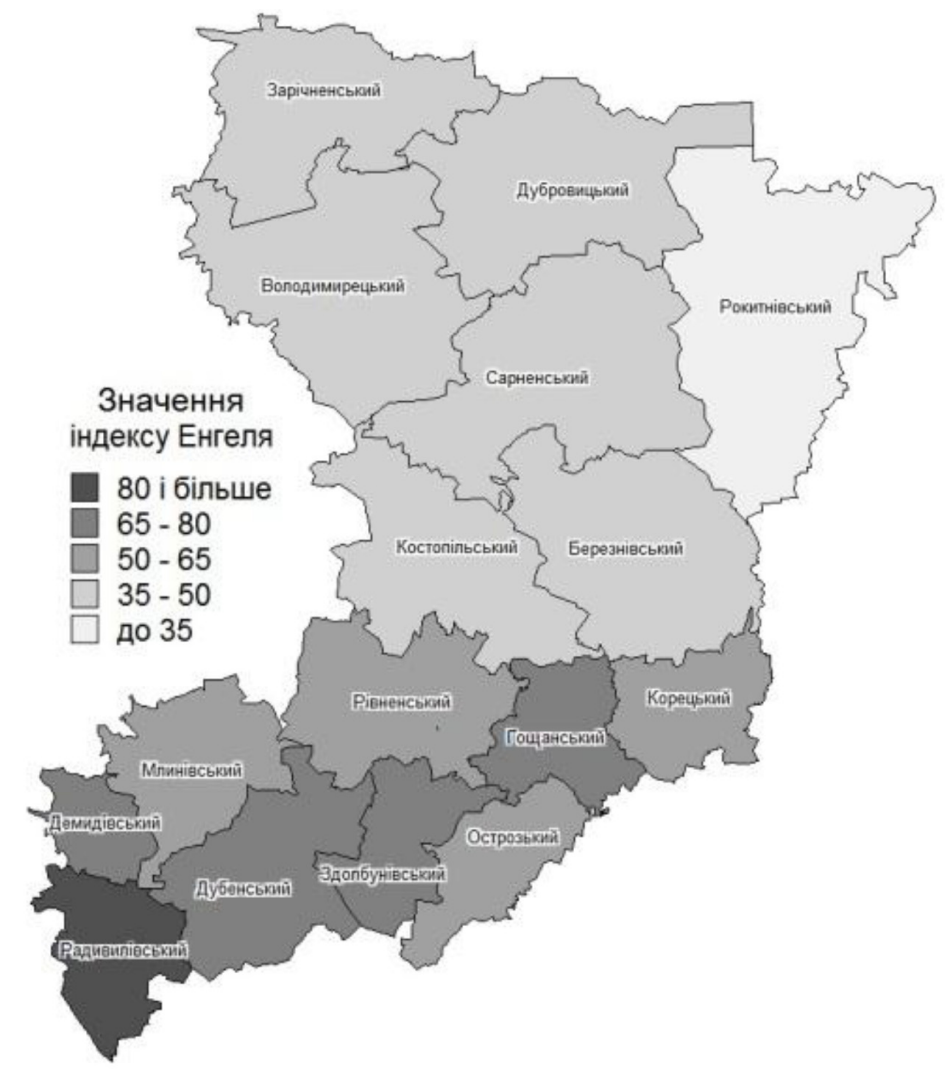

Рис. 2. Значення індексу Енгеля за адміністративними районами Рівненської області Побудовано за результатами обрахунків

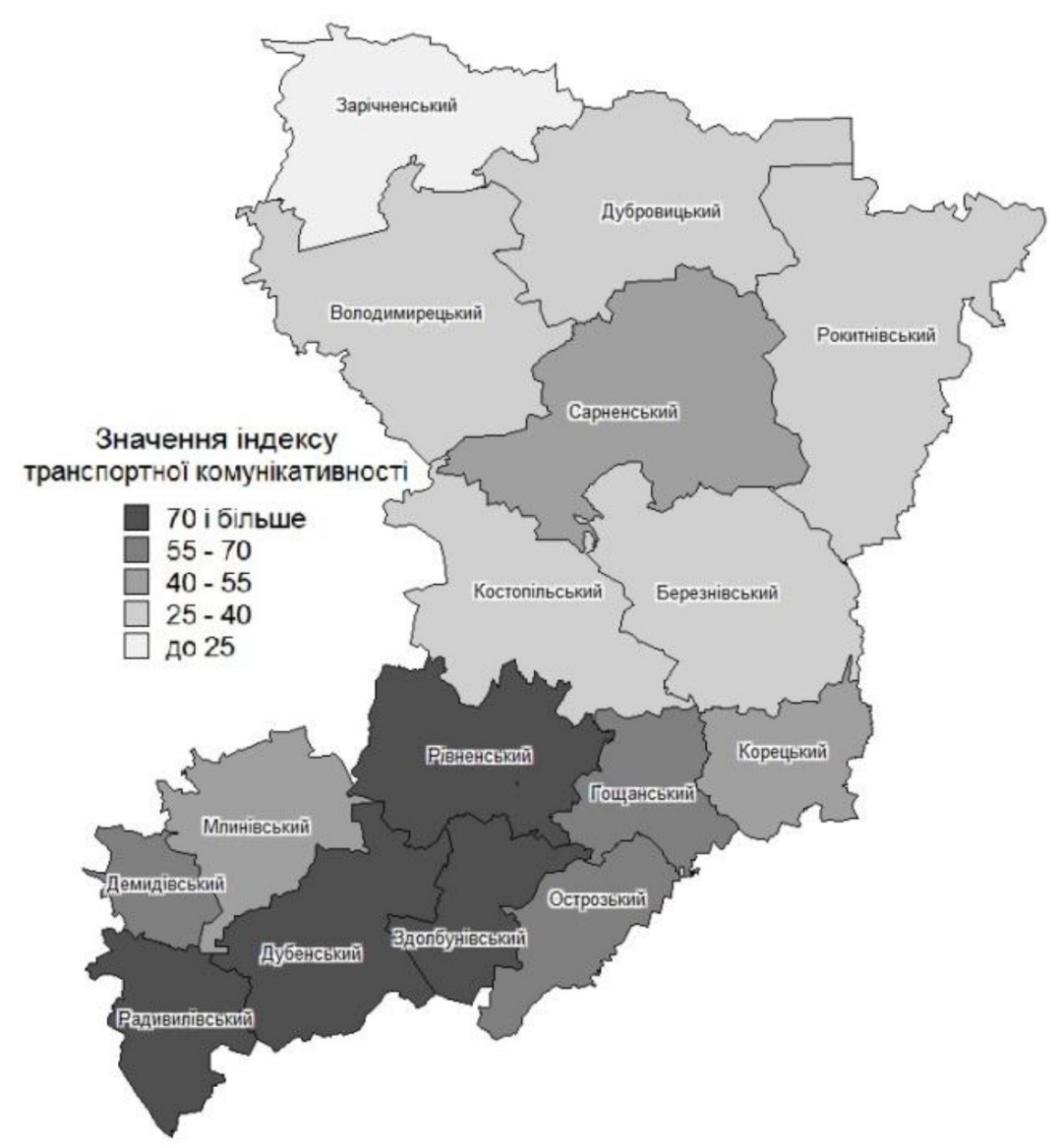

Рис. 3. Значення індексу транспортної комунікативності за адміністративними районами Рівненської області. Побудовано за результатами обрахунків 
Але даний показник є абсолютним і не враховує розбіжності у розмірі території, що не дає змогу порівняти між собою території за даним показником. Тому варто обраховувати індекс територіальної комунікативності регіону, який демонструє показник комунікативності, що у середньому припадає на одиницю площі адміністративної одиниці досліджуваної території (3):

$$
I k t=I k / S
$$

де $I k t$ - індекс територіальної комунікативності; - індекс комунікативності; $S$ - площа досліджуваної території.

По території області (рис. 3) він у середньому складає 47 - від 19 на крайній півночі області у Зарічненському районі, до 83 на крайньому півдні області у Радивилівському районі та у Рівненському районі - навколо обласного центру [4].

Така ситуація корелюється із загальними особливостями територіальної організації господарства та населення області, із природними особливостями території та iï суспільно-географічним положенням у межах території країни.

Висновки i перспективи подальших розвідок. У даному дослідженні основну увагу сконцентровано на кількісних показниках розвитку транспортної інфраструктури Рівненської області. Проте, наявність розвинутої та розгалуженої мережі автомобільних доріг та залізниць не може повністю висвітлювати рівень комунікативності населення території, оскільки для його оцінки необхідно враховувати хоча б забезпеченість населення власними автомобілями та рейсами автобусних маршрутних транспортних засобів, режим руху залізничного транспорту. Обрахунки на базі таких показників дадуть можливість оцінити також рівень часової комунікативності периферійних територій області із ядром. Також важливою характеристикою, яку варто враховувати під час комплексного дослідження рівня комунікативності якість автомобільних шляхів, залізниць та рухомого їх складу.

\section{References:}

1. Gladkij O. V., İŝuk S. Ì. Geografiâ mist. Geourbanìstika: Pidručnik [Urban Geography. Geourbanistics: Textbook]. Kyiv, 2014, 300 p. (In Ukrainian).

2. Order of the Chairman of Oblast State Administration "On approval of the list of public roads of local importance in Rivne oblast” № 307 dated 19 June 2012. Access mode: rv.gov.ua (In Ukrainian).

3. Scheme of Lviv railway. Official website of Lviv railway. Access mode: http://railway.lviv.ua/info/maps. (In Ukrainian).

4. Sëmina I. A., Folomejkina L. N. Prostranstvennyj analiz v regional'nom issledovanii transporta s ispol'zovaniem GIS-tehnologij [Spatial analysis in regional transport study using GIS-technologies]. Naučnyj žurnal Permskogo universiteta. Geografičeskij vestnik. Social'no-èkonomičeskaâ geografiâ [Scientific journal of the Perm University. Geographical bulletin. Socio-economic geography], 2009, Vol. 2(10). (In Russian). 